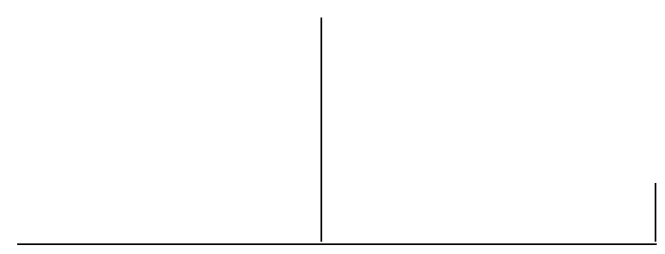

Rev. Latinoam. Psicopat. Fund., X, 2, 255-273

\title{
Esperança não é esperar, é caminhar Reflexões filosóficas sobre a esperança e suas ressonâncias na teoria e clínica psicanalíticas*
}

Zeferino Rocha

\begin{abstract}
Depois de uma breve introdução na qual são definidos o objetivo e o roteiro do artigo, o autor comenta, na primeira parte, dois fragmentos de Heráclito de Éfeso, como ponto de partida para uma abordagem filosófica da esperança, e, em seguida, define seu papel e função na dinâmica da temporalidade humana. Na segunda parte, são discutidas as possíveis ressonâncias desta visão filosófica da esperança sobre a questão dos ideais, o trabalho do luto e da melancolia, bem como seu papel no tratamento analítico dos assim chamados "clientes sem esperança".
\end{abstract}

Palavras-chave: Esperança, temporalidade humana, luto, melancolia, pacientes sem esperança

* O presente artigo foi apresentado, sob forma de conferência, na Abertura no X Encontro Psicanalítico do Centro de Pesquisa em Psicanálise e Linguagem (CPPL) da Cidade do Recife, no dia 26 de maio de 2005. 


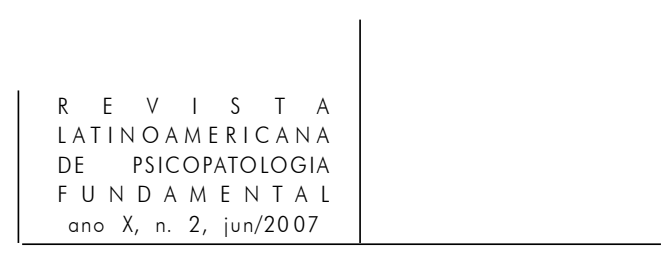

\section{Introdução}

Se não se espera, não se encontrará o inesperado, pois ele não é encontrável e é sem acesso.

Heráclito de Éfeso

Embora grandes mestres do pensamento psicanalítico, como Melanie Klein e Winnicott, tenham lembrado o papel indispensável da esperança em seus textos clínicos, não se pode deixar de reconhecer que muito pouco se fala e se escreve sobre a esperança nas publicações e nos meios psicanalíticos. Portanto, querer trabalhar o tema da esperança em uma Revista de Psicanálise não é só um desafio, mas uma tarefa de grande atualidade e de notória relevância. E como a esperança pode ser discutida sob diferentes pontos de vista, oportuno se faz, desde logo, definir qual o objetivo do presente ensaio e descrever o roteiro metodológico que pretendo seguir para alcançá-lo.

\section{Objetivo e roteiro}

O discurso sobre a esperança quase sempre nos faz pensar na virtude que, juntamente com a fé e o amor, forma a tríade das virtudes teologais da religião cristã. E não é de estranhar que assim seja, porquanto foi a tradição bíblico-cristão que enalteceu e deu um lugar de destaque à virtude da esperança. Sua conceituação teológica, desde a idade patrística tanto grega quanto latina, terminou fazendo parte essencial da formação religiosa que tanto marcou a nossa cultura ocidental.

A mesma coisa não aconteceu com a tradição filosófica. Enquanto é de meu conhecimento, muito pouco os filósofos gregos escreveram e falaram sobre a esperança. Eles não lhe dedicaram um 


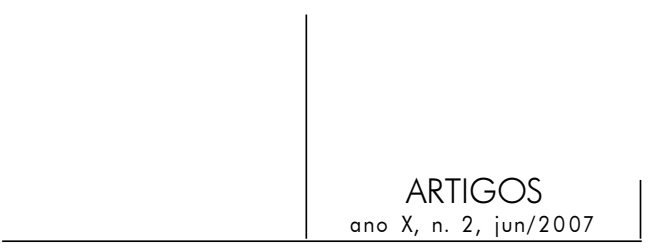

lugar de destaque no conjunto de suas doutrinas e a razão disso talvez seja o fato de que em uma Weltanschauung marcada pela concepção cíclica do tempo - na qual era soberana a idéia do destino, personificado nas figuras das Moiras, às quais até os deuses eram sujeitos - não havia espaço para se falar em esperança. Como quer que seja, mesmo quando Aristóteles, na Ética a Nicômaco, trabalhou detalhadamente as virtudes noéticas e dianoéticas, ele não se deteve no estudo da esperança, como fez com o de outras virtudes, tais como a prudência, a justiça e a amizade.

Os textos gregos que mais falam sobre a esperança são também os textos religiosos, ou seja, aqueles consagrados aos cultos dos mistérios e ao culto dos mortos. Neles, fala-se com freqüência em esperança. Os adeptos desses cultos, como lembra o hino homérico a Deméter, quando purificados pelos rituais sagrados, cultivavam a esperança de ter assegurada uma melhor sorte na região dos mortos.

Com o advento do Cristianismo, a virtude da esperança adquiriu um novo estatuto teórico, no momento em que foi contextualizada nas coordenadas de uma nova Weltanschauung de natureza eminentemente teocêntrica e inserida em uma nova concepção do tempo e da história, que se tornou o cenário da História da Salvação. Para os fiéis, esta história teve um começo (a criação), um ápice (a encarnação e a redenção) e terá um fim (a Jerusalém celeste). Nela, a esperança tem um lugar de realce, porque é sua força que sustenta a caminhada do povo de Deus através dos tempos. A fé, sustentada pela palavra de Deus, dá aos que crêem a certeza das "coisas que não se vêm”, mas a realização plena desta promessa só se fará no fim dos tempos. Pois bem, é a esperança que, durante o tempo da peregrinação terrestre, liga a certeza do objeto da fé, garantida pela palavra de Deus, à posse futura da felicidade que consiste na visão do próprio Deus, ou, para dizê-lo com as palavras do Apóstolo Paulo: "Hoje, vemos num espelho e de modo confuso, mas, um dia, veremos face a face" (I Cor. XIII,12).

Mas não é a esperança religiosa nem o seu lugar ou sua importância no kerigma da fé cristã, que será o objeto do presente ensaio. Minhas considerações sobre a esperança serão feitas no registro do pensamento filosófico e do pensamento psicanalítico, que, embora diferentes, complementam-se mutuamente. Dentro deste contexto, é meu propósito mostrar de que modo a esperança tem um papel constitutivo na dinâmica da temporalidade humana, especialmente quando esta, à luz da visão heideggeriana do tempo, pode ser considerada um elemento constitutivo do próprio existir do homem no mundo.

Tendo eu constatado em um trabalho anterior (Rocha, 2003), como são fecundas as ressonâncias da visão heideggeriana do tempo para um estudo mais aprofundado da capacidade criativa da transferência no espaço da experiência psicanalítica, fiquei tentado a procurar ver se a noção da esperança, revisitada no 


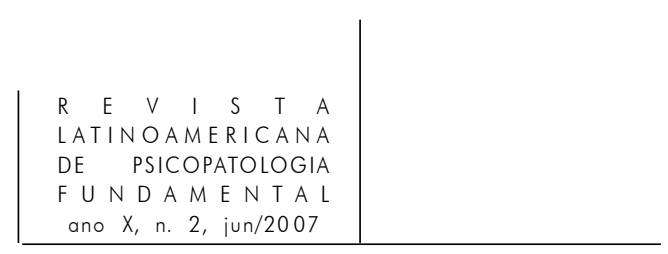

seu contexto filosófico, não poderia nos ajudar também, tanto na compreensão de alguns conceitos metapsicológicos freudianos, quanto na eficácia do trabalho analítico, particularmente com aquela categoria de clientes, que Luis Cláudio Figueiredo (2003) denominou de "pacientes sem esperança" (p. 159). Este o objetivo do presente ensaio. Para alcançá-lo, dividirei o trabalho em duas partes; na primeira, depois de lembrar e comentar brevemente dois fragmentos de Heráclito de Éfeso, nos quais, me parece, podemos encontrar uma contribuição valiosa para a abordagem filosófica da esperança, tentarei destacar a função que esta tem na dinâmica da temporalidade humana, tal como é apresentada, por Heidegger, no contexto da analítica existencial do Sein und Zeit (Heidegger, 1999).

Com isso não estou querendo dizer que o próprio Heidegger nos tenha proposto uma filosofia da esperança. Todavia na sua visão do tempo, salvo melhor juízo, acredito que se encontram subsídios valiosos para a elaboração de uma tal filosofia. Portanto, a primeira parte do presente ensaio será desenvolvida em um enfoque de natureza nitidamente filosófica. Na segunda parte, vou mostrar as ressonâncias desta análise filosófica da esperança tanto sobre a teoria quanto sobre a clínica psicanalíticas. Finalmente, à guisa de uma conclusão, farei uma breve articulação da esperança com o Eros freudiano, enquanto pulsão de vida e da desesperança com a pulsão de morte. Definidos assim o objetivo e o roteiro do ensaio, passo a desenvolver a sua primeira parte.

\section{Primeira parte}

\section{Alguns elementos para uma abordagem filosófica da eSPerança}

\section{Uma herança heraclitiana}

Vou buscar o ponto de partida desta reflexão filosófica sobre a esperança, na leitura e comentário dos fragmentos 18 e 27 do "pensador originário" Heráclito de Éfeso, escritos no século VI a.C., vale dizer, na aurora do pensamento filosófico na Grécia Arcaica. No fragmento 18, que escolhi como epígrafe do trabalho, ele proclama: "Se não se espera, não se encontrará o inesperado, pois ele não é encontrável e é sem acesso", e, de modo não menos enigmático, o fragmento 27 anuncia: "Aguardam os mortais ao morrerem, o que não esperam nem conjecturam" (Diels, 1957, p. 25).

Sem sombra de dúvida, estes dois fragmentos são enigmáticos, mas inteiramente conformes ao modo de Heráclito de Éfeso ver o mundo e as coisas que se movem no mundo. Pelos seus próprios contemporâneos, ele foi

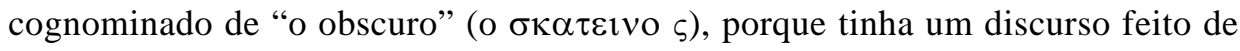




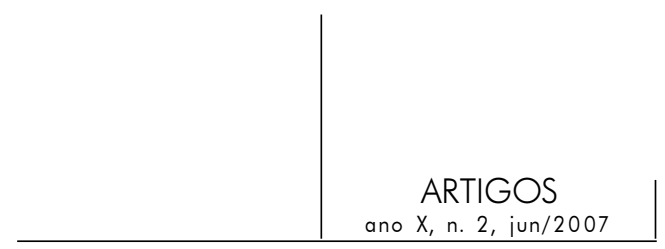

enigmas e cheio de contradições. Isto, aliás, não é de estranhar, pois tendo colocado os contrários no coração da realidade, evidentemente ele não poderia ter outro modo de pensar nem de falar. Em oposição a Parmênides, para quem "o ser é e o não-ser não é", ele afirma que "o ser é vir-a-ser", o que significa: "O ser é e não é”, posto que "está sendo". Desse modo, é compreensível que haja algo de muito profundo escondido na obscuridade de seu discurso. A este propósito, Heidegger afirma que na obscuridade do discurso do filósofo de Éfeso, existem clarões semelhantes aos dos relâmpagos, que rasgam o céu em noite de tempestade. Quando isto acontece, revela-se o que estava oculto na escuridão da noite, mas o revelado logo volta a ocultar-se, exatamente como fazem as coisas iluminadas pelo clarão do relâmpago, quando este passa.

E o que nos diz o Fragmento 18? Na linguagem enigmática que lhe é própria, ele diz que quando não se espera, não se encontra o inesperado. Ou, dito com outras palavras: quem não espera, fecha definitivamente as portas para o encontro, pois este só é possível quando se espera, quando existe uma abertura interior para o encontro. Só vê acontecer o que espera, aquele que continua esperando, não obstante todas as dificuldades que possa encontrar no caminho da procura e da espera. Todavia, mesmo quando acontece, o esperado não é encontrável porque não existem caminhos que nos levem até ele. Ele é sem acesso. Segundo Heráclito de Éfeso, o esperado não deve ser concebido como um termo a que se chega, um objeto que se encontra ou se recebe, como um prêmio que se consegue no fim da caminhada. Na sua essência, a esperança é, antes, um horizonte que se descortina, um apelo que nos convida a caminhar e a ir sempre adiante pelos caminhos da vida. "Esperança não é esperar, é caminhar". ${ }^{1}$

No meu modo de ver, é assim que Heráclito de Éfeso entende a esperança. Esta não deve ser considerada o desejo de uma "realidade objetiva" que se pode representar no presente e que se pode imaginar como uma recompensa que nos será dada no futuro, nem muito menos "algo concreto", cuja posse se consegue no fim da caminhada. Por mais obscuro que seja o seu modo de falar, o filósofo de Éfeso nos leva a pensar a esperança sob a forma de uma "disposição interior", ou de uma "força psíquica", que sustenta o desejo de caminhar. Neste sentido, a esperança só se concebe enquanto sustenta o desejo de ir na direção de um objeto que não se tem e que se o tivéssemos, extinguiria o próprio élan da esperança.

Neste contexto, a esperança, filosoficamente considerada, poderia ser comparada àquele princípio de atualização que Aristóteles atribuiu ao ato-enérgeia,

1. Frase tirada da minissérie Hoje é dia de Maria, exibida pela TV Globo. 


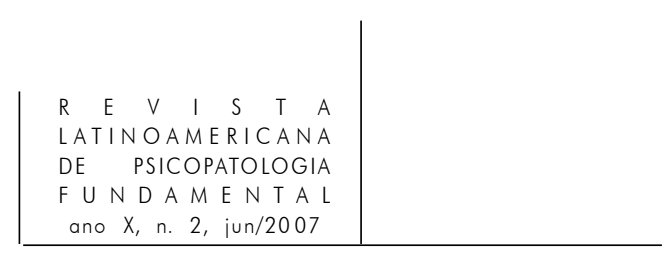

enquanto princípio ontológico da constituição do ser, vale dizer, como princípio capaz de atualizar as possibilidades existenciais em um processo de atualização, que por estar sempre em movimento, não termina nunca de se atualizar. Diferentemente do ato-enteléquia, cujo télos se obtém na constituição de um objeto determinado, o ato-enérgeia, enquanto existir movimento (tempo) não termina nunca de se atualizar no processo de atualização das possibilidades ou potencialidades de nossa existência. Ousaria dizer que é desta ordem a natureza da esperança.

Talvez seja possível apresentar uma outra maneira de descrever este modo heraclitiano de conceber a esperança, vendo, nela, aquilo que Kierkegaard denominou como a "paixão do possível", a qual atualiza as nossas possibilidades de sonhar e de projetar o futuro. (Cf. Ricoeur, 1969, p. 398). Aqui também eu não diria que o próprio Kierkegaard tenha empregado neste sentido a sua expressão. Sabe-se que ele articulou o possível com a angústia, e, na angústia, ele via a vertigem da liberdade. Mas nada impede de pensar que, enquanto "paixão do possível", a esperança é o que, em última análise, anima e impele a nossa alma peregrina, que constantemente nos faz ir adiante, impulsionando o nosso ser a caminhar pela simples alegria de caminhar e desbravar horizontes.

Esta interpretação do Fragmento 18 de Heráclito de Éfeso parece-me não estar distante da leitura que dele fez o helenista Donaldo Schüler (2000), quando escreveu: "O caminho abre-se na espera, como se fecha ao que nada espera (...) Se o encontro com o esperado se consumasse, os caminhos se apagariam, secariam os rios que navegamos e que nos atravessam, perderíamos sem recurso os cursos e domiríamos embalados no silêncio das origens" (p. 185-6).

\section{Caminhar no escuro}

Mas voltemos ao filósofo de Éfeso e reflitamos sobre o Fragmento 27, no qual a esperança é abordada no contexto dos cultos religiosos e, particularmente, do culto dos Mistérios de Eleusis, a cujos adeptos era assegurada "a esperança de uma sorte melhor no reino dos mortos" (cf. Coulanges, 2002, p. 21-5). Heráclito de Éfeso sempre teve uma atitude crítica diante dos rituais religiosos de seu tempo. Ele não valorizava as representações antropomórficas do divino e criticava os rituais de purificação. E para marcar sua oposição ao que se fazia nesses rituais ele escreve no fragmento 27: "Aguardam os mortais, ao morrerem, o que não esperam nem conjecturam". Novamente o seu discurso ilumina, de relance, a noite em que se esconde o mistério do após-morte, com um rápido clarão, que logo se apaga, para mostrar que o objeto da esperança, a quem era assegurada uma boa sorte na região dos mortos, faz parte das coisas que não 


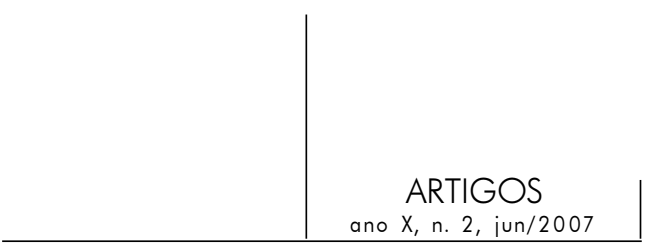

podem ser figuradas pela imaginação nem representadas pelo pensamento dos mortais. No meu entender, o filósofo de Éfeso acrescenta, neste fragmento, que quando se espera, aposta-se no escuro. Quem espera não conhece nem pode representar o objeto de sua esperança, porque este ainda não existe. Esperança, portanto, não é só caminhar como nos ensinou o fragmento 18, mas é caminhar na escuridão da noite, mesmo quando não se está em condição de poder contar com a luz de uma estrela-guia. É caminhar no escuro, vale dizer, é caminhar sem a proteção das estradas, quando caminhamos em plena luz do dia, orientados pela bússola da razão. Neste contexto, poderíamos de novo descrever a esperança como "a paixão do possível”, pois, no conceito de possível: de um lado, descortina-se a vastidão dos horizontes imensos e indeterminados (no possível tudo é possível); e, de outro lado, destacam-se a falta de segurança e a incerteza que o conceito sempre sugere, pois, no possível, nada é impossível.

\section{Um passo a mais}

Se me fosse permitido exemplificar esta maneira de conceber a esperança como um caminhar e um caminhar dentro da noite, eu lembraria um trecho do livro Terra dos homens, de Antoine de Saint-Exupéry, em que é narrada a aventura de seu amigo Guillaumet, piloto pioneiro do Correio Aéreo, surpreendido, certa vez, por uma tempestade de neve, que derrubou seu avião e o deixou perdido nas montanhas dos Andes. Inteiramente só, como um náufrago no meio de um imenso oceano de neve, ele não tinha nenhuma referência para sair daquela situação de desamparo. Nenhuma estrela brilhava no seu céu para indicar-lhe o caminho. Só lhe restava a estrela da esperança que ele trazia dentro da alma.

Depois de quatro dias, caminhando sem saber para onde, sua vontade era proteger-se contra o frio e o desespero, mergulhando de vez na noite de um sono sem fim. Por que dormir? Talvez porque, no sono, espera-se encontrar o abrigo da casa originária, simbolizada pelo útero da mãe-noite. Ou, talvez, porque na hora do desespero o ser humano se torna novamente criança e tem saudade do colo materno. Como quer que seja, no caso de nosso piloto, nem mesmo o instinto de conservação conseguia sustentar sua vontade de luta. E é aqui, neste momento de total desamparo, que surge a força da esperança. Quando o desânimo estava prestes a vencê-lo, ele dizia a si mesmo: "Se minha mulher pensa que estou vivo, ela acredita que estou caminhando". Quando sete dias depois, foi encontrado ainda com vida, ele confessou aos colegas que o salvaram: "Juro que o que eu fiz, nenhum animal teria feito" (...) E revelou o segredo: "O que me salvou foi ter tido a coragem de dar sempre um passo adiante, um passo a mais; o mesmo

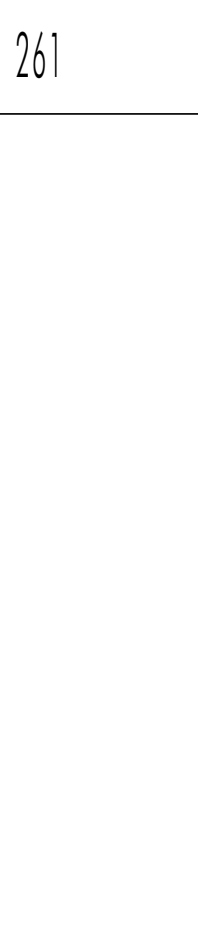




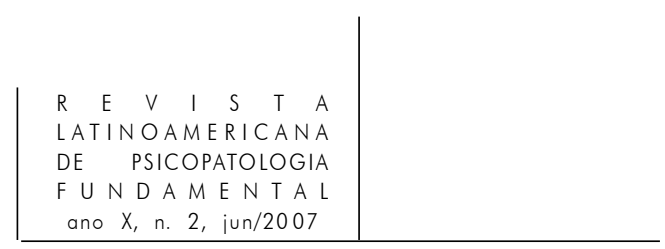

passo com que sempre se recomeça" (Saint-Exupéry, 1953, p. 160-7). Dificilmente se encontraria um exemplo mais sugestivo para nos fazer compreender que "a esperança não é esperar, é caminhar", é dar sempre um passo adiante com o qual tudo se recomeça.

Resumindo, é este o legado que nos deixou Heráclito de Éfeso para uma abordagem filosófica da esperança. Uma vez que, para ele, não se pode encontrar o que se espera e não se pode representar o objeto da esperança, pois ele está além das nossas representações, é legítimo concluir que esperar é caminhar, e caminhar no escuro, indo sempre adiante, quaisquer que sejam as dificuldades que se levantam em nossos caminhos.

Deixando a Grécia e dando um salto sobre 24 séculos da História do Pensamento Humano, vejamos, agora, como para uma abordagem filosófica da esperança, os fragmentos de Heráclito de Éfeso articulam-se ao que escreve Heidegger sobre a temporalidade humana no contexto da analítica existencial do Dasein no livro Sein und Zeit (Cf. Heidegger, 1999).

\section{A esperança na dinâmica da temporalidade humana}

As reflexões que os fragmentos de Heráclito de Éfeso nos inspiraram, encontram, segundo penso, uma fundamentação ontológica naquilo que Heidegger ensina sobre o Dasein, enquanto poder-ser (Seinkönen) e sobre a temporalidade enquanto constitutiva do Dasein. Enquanto poder-ser, o Dasein não se define como uma essência ou uma quididade objetiva ou uma "realidade determinada", mas como possibilidade, como poder-ser. Ora, a temporalidade, enquanto condição de possibilidade da existência do Dasein, é a possibilidade desta possibilidade (cf. Nunes, 2002, p. 31). Enquanto "possibilidade da possibilidade", a temporalidade é o horizonte da compreensão do ser, pois só no tempo se pode encontrar um sentido para o Dasein, que é o único dos entes que se coloca a questão do ser.

Fazendo do tempo um elemento constitutivo do Dasein, Heidegger modificou a concepção popular que sempre imaginou o tempo como algo que se desenrola fora de nós e que pode ser por nós medido. Também na concepção da filosofia clássica, o tempo se apresentava como uma sucessão linear de agoras. O presente é o eixo de sustentação desta sucessão, pois é ele a parcela do tempo que nos pertence. Nesta perspectiva, o passado já não mais nos pertence. O poeta Antonio Machado pode, então, lamentar esta dura realidade do passar do tempo, dizendo: "Ontem, é nunca mais". O que passou, passou e o passado "não mais" nos pertence, a não ser na lembrança e na saudade. O futuro também "ainda não" nos pertence, a não ser no sonho. Aristóteles deu a esta concepção do tempo uma 


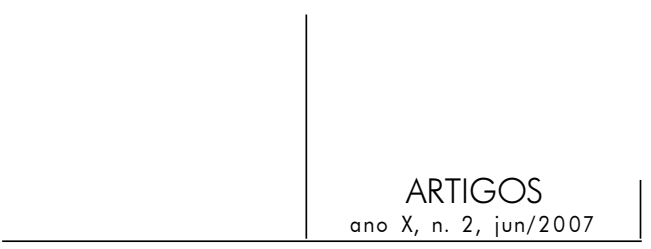

definição filosófica que se tornou célebre, quando, no livro IV da Física, escreveu: "o tempo é número do movimento segundo o antes e o depois".

Heidegger modifica este modo de conceber o tempo. Para ele, o tempo não é uma sucessão linear de agoras, pois o passado e o futuro estão intimamente inter-relacionados e mutuamente entrelaçados na dinâmica do tempo presente. $\mathrm{O}$ passado não pode nem deve ser definido como um "nunca mais", porquanto ele não perde jamais o seu vigor de ter sido. O que fomos não deixa de estar presente naquilo que somos. Heidegger, para designar esta presença renovada do passado no presente, emprega o termo Gewesenheit, que se poderia traduzir como "o vigor de ter sido", vale dizer, como aquela força, cujo vigor continua atuante ainda hoje, disto resultando um passado-presente.

O tempo presente também não se restringe a um simples agora. Na dinâmica da temporalidade humana, o presente é um Gegenwart, vale dizer, uma força de atualização, em que se misturam as forças ativas do passado - que, enquanto passado, geralmente resistem ao que é novo e isto é o que, na palavra Gegenwart, indica a preposição gegen, que quer dizer "contra" - e as forças do presente, que se projetam para o que se espera depois, para o que está por vir, como indica o verbo warten (esperar). Portanto, no instante do nosso presente, há uma luta entre o que se impõe como novidade às forças do já constituído e uma abertura para o futuro, na qual se projeta o que se espera, o que está porvir (Zukunft), mas que já está presente como projeto. Desse modo, na dinâmica do tempo presente concentram-se o vigor do ter sido (o passado) e o que "está por vir" (o futuro) e, na tensão destas duas forças contrárias, forma-se a dialética do instante da decisão, mediante o qual o homem assume, ou recusa, o projeto existencial que o define como ser no mundo. E Heidegger adverte que, nesta decisão, o Dasein, ou se assume como projeto, ou se perde no anonimato de uma existência inautêntica.

Mas, em última análise, o que decide da autenticidade, ou inautenticidade da existência é o fato de o homem, ao se assumir como possibilidade, assumir também a possibilidade da impossibilidade de todas as suas possibilidades; ou seja, assumir-se como um Sein zum Tod, como um "ser para a morte". É a morte que dá ao Dasein um sentido de totalidade, pois quando ela acontece o "da" do Dasein não é mais a clareira, na qual se manifesta o ser dos entes. Impossibilidade das possibilidades, a morte é também a impossibilidade do Dasein, porque quando ela acontece, não haverá mais tempo e o tempo, como vimos, é constituinte do Dasein. Portanto, nesta concepção heideggeriana do tempo, poderíamos ver a morte como o "não mais" das possibilidades que definem o Dasein. Todavia, a este "não mais", opõe-se um "ainda não", que é precisamente o tempo do possível e, enquanto tal, o tempo da esperança. 


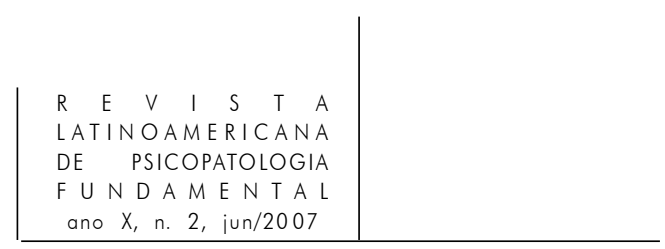

Embora esta conclusão não tenha sido tirada pelo próprio Heidegger, creio, porém, que ela se harmoniza com o seu pensamento referente à concepção da temporalidade humana. Na dialética da existência ao "não mais" imposto pela morte das possibilidades, contrapõe-se o "ainda não", como tempo da esperança. O "ainda não" da esperança volta-se para o futuro, mas sem deixar de fincar suas raízes no presente, como solo revigorado do ter sido, tempo de nossas decisões e escolhas. E é isto que distingue a esperança de uma simples quimera.

\section{Esperança e miragem}

Os sonhos sustentados pela esperança não se desmancham como se fossem quimeras ou puras miragens. Há um provérbio alemão que traduz bem isto que estou tentando dizer. Ei-lo: "Träume nicht dein Leben, lebe deinen Traum", ou seja, "Não sonhes a tua vida, vive o teu sonho". Sonhar a vida seria vivê-la, refugiando-se nas ilusões sedutoras de uma vida inautêntica, ou perdendo contato com os limites e frustrações que nos impõe a realidade de nossa existência cotidiana. Viver o sonho é olhar o futuro sem perder contato com o presente, revigorado pela força atuante de um ter sido, que estrutura nosso existir abrindoo para a dádiva das ressignificações. Viver o sonho e não deixar que ele se torne uma mera expectativa ilusória, é começar a realizá-lo desde o instante presente. Não sendo assim, todo amanhã é miragem, pois "vive-se agora ou não se vive nunca”. O nosso amanhã será do tamanho de nossa capacidade de sonhar. Mas se para sonhar o futuro abdicamos de viver pisando o chão do presente, podemos estar correndo o grande risco de transformar nossos mais belos sonhos em tristes e decepcionantes miragens.

Do que foi dito, creio poder concluir, ao menos provisoriamente, que $a$ esperança é um elemento constitutivo do existir humano no tempo, pois é ela que sustenta a abertura para o futuro do poder-ser que nós somos, e é ela que nutre a nossa capacidade de sonhar e de caminhar, sem o que viver seria "uma paixão inútil". E nisto Heráclito de Éfeso e Heidegger se encontram, pois para os dois: esperar é caminhar e caminhar é a própria vida. Vejamos, agora, as ressonâncias que esses elementos de uma possível filosofia da esperança podem ter sobre a teoria e a clínica psicanalíticas. 


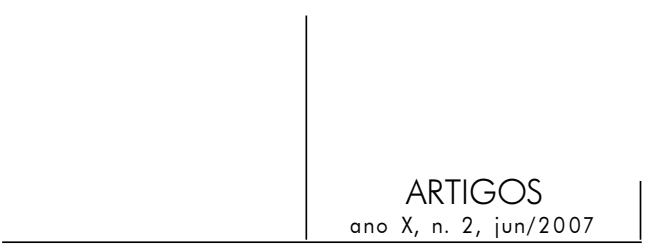

Segunda Parte A ESPERAnÇA no CAMPo da PESQUisa PSICANALítica

A esperança e a questão dos ideais

Diz-se freqüentemente que o mundo contemporâneo é um mundo sem ideais, porque, nele, vivemos entre as ilusões da Modernidade e as desilusões da Pós-modernidade. Por ilusões da Modernidade entendo aquelas criadas pela razão que se tornou o eixo do universo simbólico da Idade Moderna e dominou o Ocidente Pós-renascentista, principalmente nos últimos séculos do milênio passado. Refiro-me à razão científica e à razão técnica, que substituíram a razão clássica dos antigos e dos medievais. Na Modernidade, a razão técnica determinou não só as representações e os objetos do nosso pensar, mas também os fins do nosso agir. Transformador do mundo, o homem moderno tornou-se também o criador de si mesmo e de sua ética. Todavia, o projeto da Modernidade terminou voltando-se contra o próprio homem.

Mas para introduzir a questão dos ideais, vou lembrar que a razão técnica nos impôs uma tremenda desilusão. A Modernidade creditou-lhe uma confiança ilimitada, que se traduziu na esperança de um progresso sem limites, na crença em verdades absolutas, no fascínio de sistemas filosóficos omnicompreensivos e totalizantes e nas ideologias salvadoras, pelas quais tantos dos nossos amigos, vendo nelas o sentido mesmo da história, sacrificaram suas vidas. Esta confiança, porém, sofreu uma tremenda desilusão. Rasgaram-se as bandeiras de nossos ideais. Os grandes sistemas unitários e totalitários esfacelaram-se. Não alimentamos mais utopias quanto ao futuro. Desde o momento em que o homem moderno, com o extraordinário poder da ciência e da técnica pode decidir que não haja mais futuro para a humanidade, o futuro deixou de representar uma mensagem de esperança e se tornou uma ameaça de destruição e desespero. Disse Hannah Arendt (1994) que nossos jovens vivem hoje na tremenda insegurança de poder não ter um futuro (p. 22). Mas a questão decisiva é a seguinte: Pode-se viver sem ideais? Como a psicanálise freudiana se posiciona diante da questão dos ideais?

\section{Freud e a questão dos ideais}

Filho e crítico da Modernidade, Freud, como era de esperar, não podia não ser ambivalente a este respeito. De fato, de um lado é inegável que ele compartilhou do utopismo da razão moderna. Bastaria lembrar a última frase do 


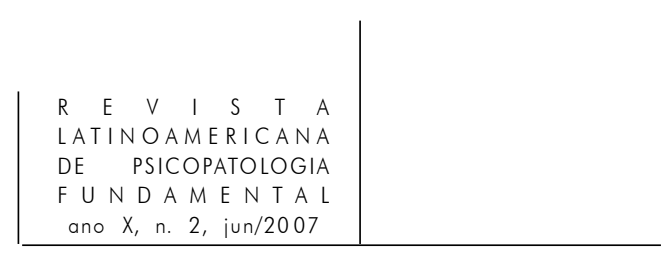

futuro de uma ilusão: "Não, a nossa ciência não é uma ilusão. Uma ilusão, no entanto, seria acreditar que, nós poderíamos encontrar noutro lugar, o que ela não nos pode dar ". (Freud, 1927, p. 89). Por causa desta adesão à utopia moderna, pode-se dizer que o sonho de Freud (do qual ele nunca abriu mão completamente apesar de todos os desmentidos de suas descobertas) e que tinha todas as características de uma "utopia iluminista", era querer encontrar, segundo o modelo das ciências da natureza (Naturwisssenschaften), um registro epistêmico para a ciência que ele construiu a partir de suas experiências clínicas. Mas Freud foi também um crítico da razão moderna e, enquanto tal, sua adesão ao otimismo iluminista não podia ser senão moderada, porquanto ele sabia que a serviço da pulsão de morte, a tecnociência poderia contribuir para as guerras e para a destruição da humanidade. ${ }^{2}$

No que se refere aos ideais propriamente ditos, embora não se possa dizer que Freud os tenha desvalorizado - ele próprio se queixou, dizendo: "porque destruímos as ilusões [weil wir Illusionem zerstören], acusam-nos de que colocamos em perigo os ideais [wirft man uns vor, dass wir die Ideale in Gefahr bringen]" (Freud, 1910, p. 129) - é preciso reconhecer que ele não se deteve na consideração de sua realidade nem de seu valor axiológico (Cf. Da Poain, 1998, p. 133-40). Na dinâmica dos processos psíquicos, Freud, enquanto "mestre da suspeita" e a psicanálise freudiana empenharam-se de preferência na discussão do processo da genealogia e da constituição psíquica dos ideais, ligados à economia dos investimentos libidinais.

Pois bem, os investimentos do ego, quando têm como modelo as ambições narcísicas do ego ideal - forjado pelo ego infantil segundo o modelo onipotente das figuras parentais - dão origem às idealizações, e, no registro destas idealizações, os ideais tornam-se ilusões que não resistem à prova da realidade. Quando referida ao objeto, a idealização faz dele um substituto do ego ideal, ou, então, um substituto do "objeto perdido". Assim também acontece, mutatis mutandis, com o objeto da paixão amorosa, com o objeto droga e também com os objetos do fanatismo seja ele religioso ou político. Foi nesta perspectiva que Freud elaborou a crítica da ilusão religiosa. Freqüentemente a psicanálise freudiana costuma estender aos ideais em geral, a crítica que Freud fez da ilusão religiosa. Tira-se então, desta premissa, uma pseudoconclusão, quando se afirma que é impossível viver os ideais sem neles nos alienarmos. Segundo meu modo de ver,

2. Leiam-se os textos sobre a "Desilusão da guerra" em "Reflexões atuais sobre a guerra e a morte" (Freud, 1915) e a Carta intitulada "Por que a guerra?" escrita a Albert Einstein em 1933. Leiase, sobretudo, "O mal-estar na cultura (1930). 


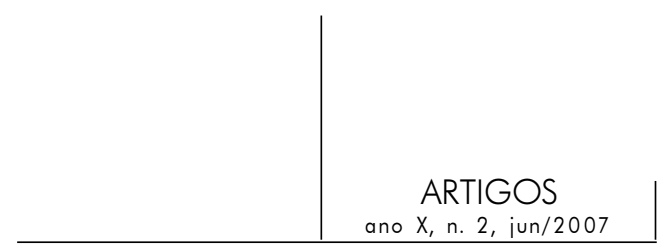

esta maneira de abordar a questão dos ideais é uma conseqüência do fato de não se fazer a devida distinção entre ego ideal e ideal do ego. Uma vez que ela não está explícita no texto freudiano, muitos não a reconhecem como necessária, nem muito menos como uma exigência das formulações sistêmicas e correlações estruturais do pensamento psicanalítico de Freud.

Não sendo nosso objetivo, no presente ensaio, trabalhar mais detalhadamente esta questão dos ideais, direi apenas que o ego ideal é uma instância pré-edípica de natureza narcísica, inteiramente constituída no registro do imaginário, tendo como modelo a onipotência das figuras parentais. Quando é inteiramente investida no ego, a libido produz a ilusória sensação de plenitude, na qual não há lugar para a falta nem para o desejo, nem por conseguinte para a esperança, tal como a apresentamos em nossa abordagem filosófica. O ideal do ego, ao invés, é uma instância pós-edípica, porquanto supõe a experiência e aceitação da castração simbólica, indispensável para que se instalem as relações verdadeiramente intersubjetivas. Ele oferece ao sujeito um modelo de identificação, sem o qual dificilmente este assumiria sua posição de sujeito.

Em vez das idealizações que, como vimos, dominam as ilusões narcísicas do ego ideal, o ideal do ego põe em movimento outros dispositivos. Entre eles, o mecanismo da sublimação tem um lugar de destaque. Neste, tanto a falta é assegurada, quanto o sujeito tem garantida a possibilidade de trabalhá-la como aquilo que permite a mobilidade de investimentos objetais diferentes do ego. Como observou Carmen Da Poian (1998), este trabalho sublimatório do ideal do ego sobre os objetos, só é compreensível se primeiramente for feita a realização de um trabalho de luto sobre as idealizações ilusórias do ego ideal.

Quando se trata das idealizações fundadas na crença ilusória de uma plenitude narcísica, é evidente que não se pode falar em esperança, pois onde há plenitude não há lugar para a falta, nem para o desejo e só o desejo e a falta descortinam horizontes para a esperança. Freud lembra que as miragens narcísicas do ego ideal acontecem, porque sentimos dificuldade de abandonar aquela posição libidinal inatacável, característica de um "estado de bem-aventurança psíquica", que foi por nós vivido quando éramos crianças (Freud, 1914, p. 55).

Mas os ideais, enquanto projetos do ideal do ego, em vez de fechar o Eu em uma ilusória plenitude narcísica, torna possível, através da sublimação e da capacidade criativa do $\mathrm{Eu}$, a abertura de novos horizontes e de novos investimentos objetais e quando novos horizontes se descortinam há sempre lugar para a esperança, pois ela vive de horizontes. 


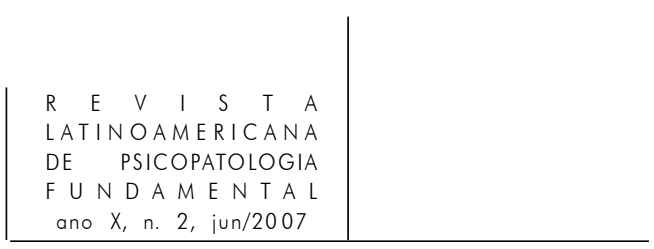

\section{O trabalho do luto e da melancolia}

Passo agora, brevemente, a considerar o trabalho do luto e da melancolia, com o intuito apenas de ressaltar um aspecto da sua problemática, ou seja, mostrar que a dor da perda no trabalho do luto se diferencia daquela que domina a melancolia, exatamente porque, no luto, a dor da perda é sustentada pela esperança, enquanto, na melancolia, ela é vivida na ausência da esperança e na dor do desespero.

No trabalho do luto, diz Freud, o mundo se esvazia, porque quem chora a perda de alguém, concentra toda sua libido na lembrança do que está sendo pranteado. O trabalho do luto é uma análise detalhada de todos os pormenores através dos quais se investiu o objeto, cuja ausência é causa do trabalho de luto. De fato, na vida estamos continuamente criando laços e nos ligando às pessoas e às coisas que amamos. No trabalho do luto, procura-se desmanchar, um por um, esses laços e desfazer, um por um, todos os nós que nos ligaram aos objetos de nossos investimentos afetivos. Freud resume o essencial do trabalho do luto em duas palavras: Lösung e Ablösung. A palavra Lösung significa solução, mas, no contexto do luto, ela poderia ser traduzida pela expressão "soltar laços", "desfazer nós". Tudo isso em vista de uma Ablösung, ou seja, de uma "substituição", precisamente a substituição do objeto, cuja perda se chora no trabalho de luto. Esta só será feita quando todos os laços tiverem sido soltos e os fios estiverem novamente em condição de poderem ser usados para fazer novos laços e para dar novos nós.

Sabe-se que Freud falou de uma viscosidade da libido que dificulta o trabalho de desinvestimento libidinal. No luto, não se trata de destruir laços. Isto, certamente, seria mais fácil do que desinvesti-los. Os investimentos libidinais são sempre acompanhados por uma série de inúmeras motivações e implicações inconscientes. Daí porque o trabalho de luto só pode ser medido pelo tempo interior de cada um, pelo qual cada um de nós é constituído na sua existência cotidiana.

Se o trabalho de luto é dinamizado pela pulsão de vida e abre horizontes para novos e inesperados encontros e investimentos, o trabalho do melancólico é inteiramente dominado pela pulsão de morte e por meio de uma identificação narcísica com o objeto ausente, o melancólico perde o amor pela vida. Freud explica que o melancólico sabe quem, mas não o que perdeu com a perda de seu objeto de amor (er weiss wen, aber nicht was er an ihm verloren hat) (Freud, 1917, p. 199). Na verdade, ele perdeu a esperança, que sustenta e nutre o amor pela vida, ou para dizê-lo com as palavras do próprio Freud: na melancolia "há uma superação da pulsão altamente significativa do ponto de vista psicológico que 


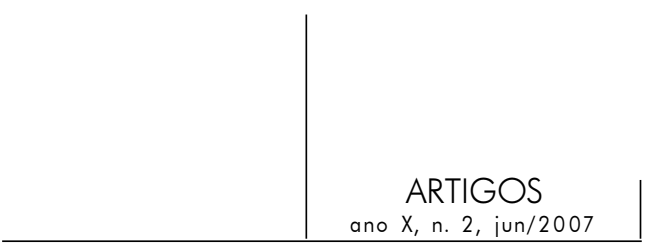

compele todo ser vivo a se apegar à vida" (eine psychologisch höchst merkwürdige Überwindung des Triebes, der alles Lebende am Leben festzuhalten zwingt”) (ibid.).

Donde o vazio que se instala no ego do melancólico. Se durante o trabalho do luto, é o mundo que se esvazia; na melancolia, quem se esvazia é o próprio ego do melancólico. Sem esperança, o mundo do melancólico é um mundo sem horizontes, é um mundo sem ideais. Seu ideal do ego é substituído por um superego tirânico e sádico que o leva a transformar em ódio toda sua capacidade de amar e a retornar este ódio contra a sua própria pessoa. Donde a tendência suicida tão freqüente no quadro clínico da melancolia. E isto me leva a abordar o último tópico, reservado precisamente a mostrar o papel decisivo da esperança no tratamento de casos difíceis que desafiam a clínica psicanalítica.

\section{Os clientes sem esperança}

Não dispondo de um material clínico obtido pela minha experiência pessoal, vou utilizar as observações de Luis Cláudio Figueiredo, apresentadas no sétimo capítulo de seu excelente livro Psicanálise, elementos para a clínica contemporânea. Na proximidade de autores kleinianos e winnicottianos, ele propõe que se veja a esperança como um princípio organizador da vida psíquica, indispensável para seu bom funcionamento, e deixa bem claro que não se refere à esperança como paixão, afeto ou vivência, nem a um estado consciente de otimismo, mas à esperança-princípio que, enquanto tal, tem um papel fundamental no funcionamento da vida psíquica e na estruturação da subjetividade humana.

Se em nossa abordagem filosófica, a esperança, enquanto abertura para o futuro e atualização das possibilidades de nosso Seinkönnen (poder-ser), foi por nós considerada constituinte da existência do nosso ser-no-mundo, é compreensível que ela possa também ser olhada como um princípio constituinte do psiquismo. São duas abordagens que, por caminhos diferentes, encontram-se tentando dizer a mesma coisa, ou seja, a importância fundamental da esperança na vida do homem.

Habitualmente se diz que a psicanálise se preocupa apenas com o passado do indivíduo, porque Freud mostrou que as vivências dos primeiros anos são decisivas para selar o destino de nossas doenças ou de nossa saúde psíquica. $\mathrm{O}$ que somos hoje começou a ser construído por aquilo que fomos ontem e o que seremos amanhã dependerá de nossa capacidade de sonhar, hoje. Pois bem, como vimos, a esperança sustenta esta capacidade de sonhar, alimenta as fantasias de 


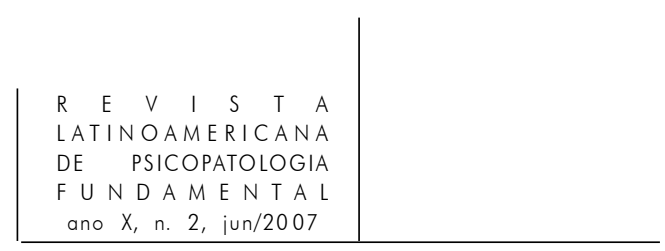

desejo e cria nossos projetos de amanhã. Assim sendo, não seria difícil mostrar que todo trabalho clínico é sustentado e impulsionado pela esperança.

Por isso, são desastrosas as conseqüências terapêuticas, quando se lida com a desesperança, sobretudo quando o que está em questão não é apenas $o$ sentimento de esperança, mas a esperança como princípio, porque quando esta falta, instala-se o que Winnicott chamou de "desesperança congênita", aquela que surge na ausência de um ambiente favorável quando da relação com os objetos primários e, sem este ambiente favorável, nenhuma estruturação de nossa vida psíquica é possível.

Luis Cláudio Figueiredo (2002) mostra-nos que a ausência dessa esperançaprincípio cria serias dificuldades para o trabalho analítico com pacientes difíceis, tais como os esquizóides, os borderlines, os pacientes falso-self e os narcisistas, "pacientes impacientes que não sabem nem podem esperar e vivem angústias desesperadas." (p. 166). Nesses pacientes, diz ele citando a psicanalista grega Anna Potamianou (1992): “A esperança cria uma defesa contra a queda no nada (nada do objeto, da relação e do self), funcionando como a base para a reconstrução do psiquismo. E adverte que se esteja atento para uma dificuldade que existe no manejo técnico quando da emergência desta esperança. Ela costuma provocar grande angústia nos clientes marcados pela desesperança. Para contornar o problema, se faz necessário que tais pacientes encontrem um objeto de sustentação no setting e na pessoa do analista. Criar este clima e ambiente de sustentação é muito mais importante do que animá-los com "discursos esperançosos". A angústia provocada pela desesperança é aterrorizadora porque está impregnada pela ameaça da destruição e da morte. Ela se manifesta clinicamente "nas passagens a ato", na "fúria dos pacientes narcisistas", nas "atuações encenadas dos esquizóides", nas "reparações exaltadas dos maníacos", ela também pode caracterizar, fora do quadro psicopatológico, "uma posição de indiferença e de egoísmo" ou de "insensibilidade ao sofrimento alheio".

Sabe-se que os traumas para nossa constituição psíquica tanto podem ser vitalizantes como devastadores. O destino depende da proporcionalidade entre a magnitude do trauma e as reservas narcísicas do ego traumatizado, mas sobretudo da presença ou ausência de um ambiente favorável. Mas é preciso não esquecer que muitas vezes as próprias experiências traumatizantes podem introduzir no ambiente um certo vigor pulsional, indispensável sobretudo quando o ambiente é ameaçado pela desesperança.

Winnicott lembra que o ambiente pode tornar-se traumatizante seja pelo excesso de presença (as mães invasivas) quanto pelo excesso de ausência (as mães ausentes). É precisamente na dinâmica alternada da presença e da ausência que o ambiente pode assegurar o clima em que a esperança fundamental se instala. Juntamente com Winnicott, Figueiredo lembra que a experiência traumática gera quase sempre um movimento de retraimento ou de regressão. Se naquele, o sujeito 


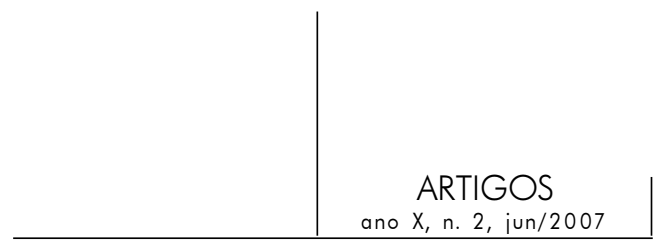

se defende pela procura de uma certa auto-suficiência, nesta o "trauma é liquidado" por um retorno a um certo modo de contato com o ambiente primordial e seus objetos. Fazendo isso, o sujeito "recupera a confiança em si e no meio, em si e no outro". Quando esta regressão revitalizante não é possível, pelo fato de não se poder contar com um "objeto suficientemente bom”, opera-se uma cisão no sujeito, na qual ou o "infantil afetado pelo trauma é congelado e mantido no estado de dissociação; ou, então, "uma parte do psiquismo cresce no sentido de uma pretensão à auto-suficiência absoluta". Estaria aqui o segredo da desesperança que domina a vida dos doentes esquizóides, borderline, falsos-self e narcisistas.

\section{À guisa de uma conclusão}

Se no contexto de tudo o que dissemos, podemos articular a esperança como princípio fundamental do funcionamento psíquico e da estruturação da subjetividade com a pulsão de vida (Eros) e a desesperança com a pulsão de morte, então se poderia dizer que o grande conflito que ameaça não só a nossa vida psíquica, mas toda nossa vida cultural é, em última análise, um conflito entre a esperança e a desesperança. E diante deste conflito - parodiando o que Freud (1930) escreveu no término do "O mal-estar na cultura" - poder-se-ia dizer que " só nos resta esperar que o eterno Eros desdobre suas forças para se afirmar na luta com seu não menos imortal adversário” (Freud, 1930).

E termino lembrando que, neste campo de luta, entre o "não mais" que será instalado pela morte e "ainda não" que se abre como tempo da esperança, o homem é um peregrino e seus pés não se cansam de criar novos caminhos, pois seu destino é caminhar e sua alma é uma "alma viajeira". Por isso, o fim a que chega em cada etapa de sua grande viagem, é de onde ele sempre está partindo para novas estradas e para novas aventuras. É o que nos revela, na magia da linguagem poética, esta passagem de um poema de Daniel Lima, que resume o diálogo do poeta com sua alma viajeira. É a melhor conclusão que poderia desejar para estas reflexões sobre a esperança:

Aonde irás ter, perguntas,

se de novo tiveres de seguir outros caminhos no fim desses caminhos já seguidos? Aonde irás ter?

Que adianta perguntares, agora, alma viajeira? Não o saberias nunca.

A estrada chama, a alma chama, os pés chamam, a vida chama Andar, sair, caminhar sempre, é isto o que tens a fazer, eterno peregrino, 
e é o que sempre em agonia vens fazendo

na insatisfeita busca de ti mesmo.

Vai, pois, sem nem saber aonde caminhas.

Anda sem de roteiros indagares,

que o mistério da vida, que a beleza da vida

só se dá, gratuita e plena,

a quem, andando sempre, ama a viagem,

porque a viagem é a estrada

e a estrada é a Vida.

Alma viajeira, Daniel Lima

\section{Referências}

Arendt, Hannah. Sobre a violência. Trad. e ensaio crítico de André Duarte. Rio de Janeiro: Relume-Dumará, 1994.

Coulanges, Fustel de. A cidade antiga. Trad. de Jean Melville. São Paulo: Martin Claret, 2002.

Da Poain, Carmen. O desamparo e a questão dos ideais. Desamparo. Cadernos de Psicanálise, Círculo Psicanalítico do Rio de Janeiro, ano 20, n. 12, p. 133-40, 1998.

Diels, Hermann. Die Fragmente der Vorsokratiker. Rowohlt Hamburg, 1957.

Figueiredo, Luis Cláudio. O paciente sem esperança e a recusa da utopia. In: Psicanálise. Elementos para a clínica contemporânea. São Paulo: Escuta, 2003. p. 157-89.

Freud, S. (1910). Die zukünftigen Chancen der psychoanalytischen Therapie. Studienausgabe (SA). Ergänzungsband. Frankfurt am Main: Fischer Tagensbuch Verlag, 1982.

(1914). Zur Einführung des Narzissmus. SA. Band III. S. 37.

(1915). Zeitgemässes über Krieg und Tod. SA. Band IX, S. 33.

(1917). Trauer und Melancholie. SA. Band III, S. 193.

(1927). Die Zukfunt einer Illusion. SA. Band IX, S. 189.

(1930). Das Unbehagen in der Kultur. SA. Band IX, S. 191.

(1933). Warum Krieg? SA. Band IX, S. 271.

Heidegger, Martin. Ser e tempo. Trad. de M. Márcia Cavalcanti. Petrópolis: Vozes, 1999.

NunEs, Benedito. Heidegger ser \& tempo. Rio de Janeiro: Jorge Zahar, 2002.

Potamaniou, Anna. Un bouclier dans l'économie des états-limites: l'éspoir. Paris: PUF, 1992.

Ricoeur, Paul. Liberte selon l'Éspérance. In: Le conflit des interprétations. Éssais d'hermenéutique. Paris: Édition du Seuil, 1969. p. 393. 


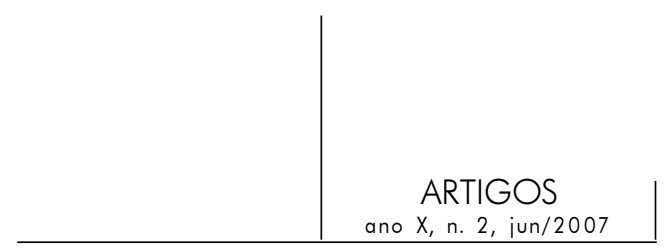

Rocha, Zeferino. Transferência e criatividade no tempo da análise. Revista Latinoamericana de Psicopatologia Fundamental, São Paulo, ano VI, n. 4, p. 80-101, dez./2003. SAINT-Exupéry, Antoine de. Le petit prince. Paris: Gallimard, 1953.

SChüller, Donaldo. Heráclito e seu (dis)curso. Porto Alegre: L\&PM, 2000.

\section{Resumos}

Después de una breve introducción en la que se definen el objetivo y el plan del artículo, el autor comenta en la primera parte, dos fragmentos de Heráclito de Éfeso, como punto de partida para un enfoque filosófico de la esperanza; a seguir, define su papel y función en la dinámica de la temporalidad humana. En la segunda parte discute las posibles resonancias de esta visión filosófica de la esperanza sobre la cuestión de los ideales, el trabajo del luto y de la melancolía, así como su papel en el tratamiento psicoanalítico de los llamados "clientes sin esperanza”.

Palabras claves: Esperanza, temporalidad humana, luto, melancolía, clientes sin esperanza

Après une brève introduction dans laquelle sont definis le propos et la méthodologie de l'article, $l$ 'auteur commente, dans la première partie, deux fragments d'Héraclite d'Éphèse, comme le point de depart d'une approche philosophique de l'espérance; ensuite, il définit le role et la foction de l'espérance dans la dynamique de la temporalité humaine. Dans la deuxième partie, sont discutées les resonances de cette approche philosophique de l'espérance sur la question des ideaux, le travail du deuil et de la mélancolie, aussi bien que son rôle dans le traitement analytique des clients dits "clients sans espérance".

Mots clés: Espérance, temporalité humaine, deuil, mélancolie, clients sans espérance

After a brief introduction, where the objective and outline of this article are defined, the author comments on two fragments from Heraclites of Ephesus as the beginning of a philosophical approach to hope. The role and function of hope are them defined in the dynamics of human temporality. In the second part, the possible resonances of this philosophical perspective of hope on the question of ideals are discussed, along with the processes of mourning and melancholia, and their role in analytical treatment of those patients described as "hopeless."

Key words: Hope, human temporality, mourning, melancholia, hopeless patients

Versão inicial recebida em março de 2006

Versão revisada recebida em setembro de 2006 